\title{
Ectomycorrhizal fungal communities of native and non-native Pinus and Quercus species in a common garden of 35-year-old trees
}

\author{
Lidia K. Trocha • Izabela Kałucka • Małgorzata Stasińska • Witold Nowak • \\ Mirosława Dabert • Tomasz Leski • Maria Rudawska • Jacek Oleksyn
}

Received: 15 November 2010 / Accepted: 2 May 2011 /Published online: 15 May 2011

(C) The Author(s) 2011. This article is published with open access at Springerlink.com

\begin{abstract}
Non-native tree species have been widely planted or have become naturalized in most forested landscapes. It is not clear if native trees species collectively differ in ectomycorrhizal fungal (EMF) diversity and communities from that of non-native tree species. Alternatively, EMF species community similarity may be more determined by host plant phylogeny than by whether the plant is native or non-native. We examined these unknowns by comparing two genera, native and non-native Quercus robur and Quercus rubra and native and non-native Pinus sylvestris and Pinus nigra in a 35 -year-old common garden in Poland. Using molecular and morphological approaches, we identified EMF species from ectomycorrhizal root tips and sporocarps collected in the monoculture tree plots. A total of $69 \mathrm{EMF}$
\end{abstract}

L. K. Trocha $(\bowtie) \cdot$ T. Leski $\cdot$ M. Rudawska $\cdot$ J. Oleksyn Institute of Dendrology, Polish Academy of Sciences, Parkowa 5,

62-035 Kórnik, Poland

e-mail: lidiatrocha@gazeta.pl

I. Kałucka

Department of Algology and Mycology, University of Łódź,

Banacha 12/16,

90-237 Łódź, Poland

M. Stasińska

Department of Botany and Nature Protection,

University of Szczecin,

Felczaka 3c,

71-412 Szczecin, Poland

W. Nowak $\cdot$ M. Dabert

Laboratory of Molecular Biology Techniques,

Adam Mickiewicz University,

Umultowska 89,

61-614 Poznań, Poland species were found, with 38 species collected only as sporocarps, 18 only as ectomycorrhizas, and 13 both as ectomycorrhizas and sporocarps. The EMF species observed were all native and commonly associated with a Holarctic range in distribution. We found that native $Q$. robur had ca. $120 \%$ higher total EMF species richness than the non-native Q. rubra, while native $P$. sylvestris had ca. $25 \%$ lower total EMF species richness than non-native $P$. nigra. Thus, across genera, there was no evidence that native species have higher EMF species diversity than exotic species. In addition, we found a higher similarity in EMF communities between the two Pinus species than between the two Quercus species. These results support the naturalization of non-native trees by means of mutualistic associations with cosmopolitan and novel fungi.

Keywords Ectomycorrhiza $\cdot$ Similarity $\cdot$ Closely related tree species $\cdot$ Non-native tree species

\section{Introduction}

Ectomycorrhizas are an important symbiosis by which many plant species in north temperate and boreal conditions cope with infertile soils. Many ectomycorrhizal fungal (EMF) species can form ectomycorrhizas with a variety of tree species (Smith and Read 2008), and closely related tree species tend to form similar EMF species communities (Horton and Bruns 1998; Ishida et al. 2007). However, different tree species of the same genus may still possess specific EMF species (i.e., Rusca et al. 2006). One of the factors making EMF species community structures similar among closely related trees is the co-evolution of both partners: fungi and host trees (Kretzer et al. 1996). 
Moreover, the speciation process during the co-evolution of tree and of fungi (Cairney 2000) and their movement into geographically and climatically distant regions (Grubisha et al. 2007) might also influence the divergence in EMF assemblages for closely related tree species. How native and non-native species of the same genus are affected in this regard remains unknown. The colonization process of non-native tree species partially consists of the niche partitioning of locally existing EMF species toward the non-native tree roots. The recognition and mycorrhiza formation of native EMF species with a new tree species is controlled by many unknown factors as demonstrated by Parladé et al. (1996) who also found incompatibility among some fungal strains of the same EMF species and Pseudotsuga menziesii seedlings.

Frequently trees grow outside of their natural ranges as a result of intentional or unintentional human activity. For example, red oak (Quercus rubra L.) and Austrian black pine (Pinus nigra Arn.) are widespread exotic species. Both tree species survive well outside their native areas (Białobok and Chylarecki 1965; Bellon et al. 1977; Zhou et al. 1997; Demchik and Sharpe 2000; Gebhardt et al. 2007) and are widely used in forestry. Furthermore, Q. rubra is considered an invasive tree species in Europe (Daubree and Kremer 1993; Petit et al. 2004; Křivánek and Pyšek 2006), although reasons for its invasiveness remain uncertain. One of the potential reasons making $Q$. rubra successful is its broad ecological range for climatic, soil moisture and $\mathrm{N}$ availability conditions and, in turn, competitive abilities against native tree species (Zerbe and Wirth 2006). Exotic plant species may be abundant in novel environments as they do not experience the same negative feedback with soil communities (Reinhart and Callaway 2006). This is a key factor in alien plant invasions and considered as "enemy escape." It is unclear how non-native tree species may utilize mycorrhizal fungi to cope with novel environments, and it is also unknown to what extent they form similar EMF assemblages as their native counterparts.

Non-native trees may form symbioses with EMF species in exotic locations through acceptance of native EMF species, increased reliance on cosmopolitan EMF species, or co-introduction non-native trees with non-native EMF species. The invasive Picea engelmannii found in North America (Cullings et al. 2000) and Q. rubra growing in Germany accepted a broad range of native EMF species (Gebhardt et al. 2007) as did non-native Eucalyptus sp. growing in the Seychelles Islands (Tedersoo et al. 2007). Kohout et al. (2010) also demonstrated that non-native Pinus strobus effectively adopted EMF assemblages with native fungi in a mesocosm experiment in Czech Republic. Similarly, Parladé et al. (1996) demonstrated that 18 EMF species out of 27 collected in northern Spain were able to colonize roots of non-native Pseudotsuga menziesii in a pure culture test. On the other hand, the intended introduction of Pinus spp. into Australia failed as a result of lack of pine-specific EMF species (Nuñez et al. 2009). However, Dickie et al. (2010a) showed that non-native Pinus contorta was successfully introduced into New Zealand mostly by means of the co-invasion of EMF species and forming ectomycorrhizal associations with cosmopolitan EMF species rather than the acceptance of novel fungi. This was also demonstrated by Tedersoo et al. (2007) for Pinus caribea which maintained EMF species co-introduced with seedlings in the Seychelles Islands.

Ectomycorrhizal fungal species are more host specific than arbuscular mycorrhizal fungi (Smith and Read 2008), and the absence of ectomycorrhizas originally hindered the success of many Pinus species to new regions of the world (Brisco 1959; Poynton 1979 in Reinhart and Callaway 2006). However, it has been shown that EMF species can migrate or be moved by human activities to remote novel places (see Vellinga et al. 2009). The global introduction and distribution of EMF species may facilitate the introduction and finally lead to the invasion of certain trees. This potential was shown by Richardson et al. (1994) for Pinus introduced into the Southern Hemisphere and also by Chou-Chou and Grace (1983) who observed a co-occurrence of Rhizopogon vinicolor (an EMF species originally from North America) with P. menziesii grown in New Zealand.

This suggests a key role for EMF in the establishment of non-native tree species in novel places. It has been shown how the non-native tree species use mutualistic symbioses to cope with growing in novel places (see above citations). However, to what extent the EMF assemblages of nonnative tree species are shared with their native counterparts remains unknown.

To gain insights into the ability of two native and nonnative trees in the genera Pinus and Quercus to share common EMF species when grown in a common garden, we addressed the following questions: (a) Is the EMF species richness higher for native tree species than for nonnative tree species? (b) Is the EMF community more similar within a tree genus than between tree genera, and is it more similar for Pinus spp. as the two are less separated geographically than the Quercus spp? (c) Do native species possess a higher number of unique EMF species? (d) Do the cosmopolitan EMF species dominate on the non-native tree species?

\section{Materials and methods}

Study site

The study was carried out at the Siemianice Experimental Forest in central Poland $\left(52^{\circ} 14.87^{\prime} \mathrm{N}, 18^{\circ} 06.35^{\prime} \mathrm{E}\right.$; 
$150 \mathrm{~m}$ a.s.1.). Fourteen tree species were planted as monocultures $(20 \times 20 \mathrm{~m}$ plots; trees were planted at $1 \times$ $1 \mathrm{~m}$ spacing) in 1970-1971 after 80-year-old Scots pine stands were clear-cut (including removal of the root systems), on two adjacent sites differing in soil properties (a coniferous forest site and a mixed forest site). Each site has three replicates of nine tree species, with four species shared between the two sites. In the present study, we used only the coniferous forest site to avoid putative effects of edaphic factors on EMF community structure. The coniferous forest site comprises plots of Quercus robur, Q. rubra, Pinus sylvestris and P. nigra (with three replicates each) as well as plots of five species not considered in this study (Betula pendula, Carpinus betulus, Larix decidua, Picea abies, and $P$. menziesii). The mean annual temperature is $8.2^{\circ} \mathrm{C}$ and the mean annual precipitation is $591 \mathrm{~mm}$. The growing season (calculated as the number of days with an average temperature above $5^{\circ} \mathrm{C}$ ) lasts on average 213 days and snow cover lasts 50-60 days. Details of soil characteristics in tree plots are presented in Table 1. Details of the experimental area and description of various aspects of tree effects on seedling mycorrhizas (Dickie et al. 2006), fungal phenology (Dickie et al. 2010b), plant invasions (Knight et al. 2008), calcium and earthworms (Reich et al. 2005; Dauer et al. 2007), leaf and fine root litter decomposition (Hobbie et al. 2006, 2010; Goebel et al. 2011), soil nutrients and biogeochemistry (Hobbie et al. 2007), root distribution and lifespan (Withington et al. 2003, 2006; Dauer et al. 2009), and soil organic matter (Hobbie et al. 2007) have been addressed in previous studies of these forest stands.

Sporocarp survey and identification

Sporocarps of all ectomycorrhizal fungi were collected for identification approximately once a month during three growing seasons from May to November in 2004,
2005, and 2006. Identification was carried out using macroscopic and microscopic characters according to standard procedures. The nomenclature follows Knudsen and Vesterholt (2008), Legon et al. (2005), and Index Fungorum (www.indexfungorum.org). The sporocarp collections were deposited in the Herbaria of the University of Łódź and the University of Szczecin, Poland.

All the species found as sporocarps were included in the analysis. Although some sporocarps may have been linked to trees growing in neighboring plots (ex. individuals of $R$. vinicolor, a species specific to $P$. menziesii, found in a $Q$. robur plot), these occurrences were likely very low and did not impact the results of the analysis.

Ectomycorrhizal survey and morphotype assessment

Soil samples (ca. $30 \mathrm{~cm}^{3}$ each) for EMF species evaluation were collected during late spring (May/June), late summer (August/September), and fall (beginning of November) in 2004 and in 2005. For each sampling, we collected nine soil samples from each monoculture plot of the four tree species studied (12 plots total, 108 samples/ collection date). The samples were collected in a $5 \times 5-\mathrm{m}$ subplot, with about $1.5 \mathrm{~m}$ grid spacing between soil cores. The subplot was in the central part of the plot to avoid any possible contamination by tree roots from neighboring plots. Samples were placed in tagged plastic bags and stored at $-10^{\circ} \mathrm{C}$ until analysis. In total, we collected 162 soil samples for each tree species studied. Separation and evaluation of ectomycorrhizal root tips was conducted under a dissecting microscope. All fine roots from each soil sample were collected and rinsed under tap water using a 1-mm sieve just before ectomycorrhizal morphotypes assessment. Ectomycorrhizal morphotypes were described based on macroscopic observations according to Agerer (1987-2003) and Ingleby et al. (1990) and also were compared to a database used in the Laboratory of

Table 1 Selected soil characteristics of organic horizon (O horizon) and upper mineral horizons (means, $n=3$ ) of four tree species growing in monoculture plots at Siemianice, Poland

\begin{tabular}{|c|c|c|c|c|c|c|c|c|c|c|c|c|c|c|}
\hline \multirow[t]{2}{*}{ Species } & \multicolumn{2}{|l|}{ Soil pH } & \multicolumn{2}{|c|}{ SOM (\%) } & \multicolumn{2}{|c|}{$\mathrm{N}_{\text {total }}(\%)$} & \multicolumn{2}{|c|}{$\mathrm{C}_{\mathrm{org}}(\%)$} & \multicolumn{2}{|l|}{$\mathrm{C} / \mathrm{N}$} & \multicolumn{2}{|c|}{$\mathrm{P}(\mathrm{mg} / 100 \mathrm{~g})$} & \multicolumn{2}{|c|}{$\mathrm{K}(\mathrm{mg} / 100 \mathrm{~g})$} \\
\hline & $\begin{array}{l}\mathrm{O} \\
\text { horizon }\end{array}$ & $\begin{array}{l}0- \\
20 \mathrm{~cm}\end{array}$ & $\begin{array}{l}\mathrm{O} \\
\text { horizon }\end{array}$ & $\begin{array}{l}0- \\
20 \mathrm{~cm}\end{array}$ & $\begin{array}{l}\mathrm{O} \\
\text { horizon }\end{array}$ & $\begin{array}{l}0- \\
20 \mathrm{~cm}\end{array}$ & $\begin{array}{l}\mathrm{O} \\
\text { horizon }\end{array}$ & $\begin{array}{l}0- \\
20 \mathrm{~cm}\end{array}$ & $\begin{array}{l}\mathrm{O} \\
\text { horizon }\end{array}$ & $\begin{array}{l}0- \\
20 \mathrm{~cm}\end{array}$ & $\begin{array}{l}\mathrm{O} \\
\text { horizon }\end{array}$ & $\begin{array}{l}0- \\
20 \mathrm{~cm}\end{array}$ & $\begin{array}{l}\mathrm{O} \\
\text { horizon }\end{array}$ & $\begin{array}{l}0- \\
20 \mathrm{~cm}\end{array}$ \\
\hline $\begin{array}{l}\text { Pinus } \\
\text { nigra }\end{array}$ & 4.08 & 4.11 & 57.55 & 1.39 & 1.25 & 0.05 & 33.37 & 0.8 & 26.98 & 17.05 & 10.95 & 0.02 & 26.14 & 0.48 \\
\hline $\begin{array}{l}\text { Pinus } \\
\text { sylvestris }\end{array}$ & 3.95 & 4.01 & 61.5 & 1.64 & 1.28 & 0.05 & 35.67 & 0.95 & 28.13 & 19.11 & 11.81 & 0.21 & 23.73 & 0.47 \\
\hline $\begin{array}{l}\text { Quercus } \\
\text { rubra }\end{array}$ & 4.86 & 4.18 & 55.19 & 1.32 & 1.45 & 0.05 & 32 & 0.77 & 22.29 & 15.03 & 20.65 & 0.27 & 64.38 & 0.81 \\
\hline $\begin{array}{c}\text { Quercus } \\
\text { robur }\end{array}$ & 4.77 & 4.15 & 50.74 & 1.48 & 1.64 & 0.06 & 29.47 & 0.86 & 17.96 & 14.42 & 18.5 & 0.11 & 47.98 & 1.0 \\
\hline
\end{tabular}


Mycorrhizal Research at the Institute of Dendrology (Iwański et al. 2006; Rudawska et al. 2006; Trocha et al. 2006). Each ectomycorrhizal morphotype was described in detail (color and structure of the surface of the mantle, shape of the ectomycorrhizal root tip, extramatrical hyphae color and structure, and occurrence of other features, e.g., cistidia), photographed, and stored in a plastic tube in the $-10^{\circ} \mathrm{C}$ until molecular analysis.

Ectomycorrhizal morphotype molecular identification

Total genomic DNA was extracted from each ectomycorrhizal morphotype or pieces of selected sporocarps (ca. $20 \mathrm{mg}$ of dried tissue) using the PLANT\&FUNGI DNA Purification Kit (EURx, Poland) according to manufacturer's protocol. For the morphotype analyses, we used from two to four root tips per morphotype (depending on the sequence quality obtained further) of each tree species. In total, each morphotype had at least two replicates or, in the case of its presence on four tree species, it had eight replicates. This allowed for an analysis of intramorphotype variation of the sequenced regions. Ectomycorrhizas formed by Cenococcum geophilum were excluded from molecular identification and were designated based on their unique morphological features. Internal transcribed spacer regions (ITS1-5.8S-ITS2) were amplified via the polymerase chain reaction (PCR) using primers: fungal specific ITS1-F (Gardes and Bruns 1993) and universal ITS4 (White et al. 1990). The PCR reactions were performed in a 10- $\mu$ l volume mixture consisting of $1 \times$ PCR buffer (Novazym, Poland), $1.5 \mathrm{mM} \mathrm{MgCl}_{2}$ (Novazym, Poland), $0.2 \mathrm{mM}$ of each dNTP (Novazym, Poland), $0.5 \mu \mathrm{M}$ of each primer, $0.02 \mathrm{mg} / \mathrm{ml} \mathrm{BSA}$ (Promega, Madison, WI, USA), 0.25 U of Taq Polymerase (Novazym, Poland), and $5 \mu \mathrm{l}$ of DNA aliquot (undiluted or $2 \times$ or $4 \times$ diluted). Reactions were performed in a T3 Thermocycler (Biometra, Germany) using the following temperature profile: $1 \mathrm{~min} 93^{\circ} \mathrm{C}$ (initial denaturation), $1 \min 95^{\circ} \mathrm{C}$ (denaturation), $1 \min 60^{\circ} \mathrm{C}$ (annealing), $2 \min 72^{\circ} \mathrm{C}$ (elongation), $10 \mathrm{~min} 72^{\circ} \mathrm{C}$ (final elongation), and $7^{\circ} \mathrm{C}$ (pause). Steps 2 to 4 were repeated 35 times. PCR products were purified by the MinElute PCR Purification Kit (Qiagen, Canada) according to the manufacturer's instructions and directly sequenced using primers ITS 1 and/or ITS 4 (White et al. 1990). DNA sequencing was undertaken using the ABI Prism Big Dye Terminator Sequencing Kit version 3.1 (Applied Biosystems, Foster City, CA, USA). Cycle sequencing was performed using a 2720 Thermal Cycler followed by capillary electrophoresis in an ABI Prism 3130XL Genetic Analyser (Applied Biosystems, Foster City, CA, USA).
In cases of sequence heterogeneity, ITS amplicons were cloned using the pGEM-T easy vector system (Promega, Madison, WI, USA) and DH5 $\alpha$ Escherichia coli competent cells (Invitrogen, Ltd., Paisley, UK) according to the manufactures' protocols. Transformed cells were incubated on Petri dishes containing LB Broth EZmix TM Powder (Sigma-Aldrich) with $1.5 \%$ agar (AppliChem $\mathrm{GmbH}$, Darmstadt, Germany) at $37^{\circ} \mathrm{C}$ overnight. About ten white clones were randomly selected for each transformation effort and subjected to colony PCR using the M13 forward (5'-TGTAAAACGACGGCCAGT$\left.3^{\prime}\right)$ and reversed (5'-CAGGAAACAGCTATGACC-3') primer pair and Taq DNA polymerase (Novazym, Poland). Reactions were performed in the following temperature profile: $3 \mathrm{~min} 96^{\circ} \mathrm{C}$ (initial denaturation), $20 \mathrm{~s} 95^{\circ} \mathrm{C}$ (denaturation), $15 \mathrm{~s} 53^{\circ} \mathrm{C}$ (annealing), $1 \mathrm{~min} 10 \mathrm{~s} 72^{\circ} \mathrm{C}$ (elongation), $5 \min 72^{\circ} \mathrm{C}$ (final elongation), and $7^{\circ} \mathrm{C}$ (pause). Steps from 2 to 4 were repeated 36 times. PCR products with amplicons of different sizes, confirmed by agarose gel electrophoresis, were subjected to another round of sequencing PCR using T7 primer (5'-TAATAC GACTCACTATAGGG-3') and to DNA sequencing (as described above). All sequencing results were compared to those deposited in GenBank and UNITE using the blastn algorithm.

All of the sequences obtained from studied morphotypes were verified by analysis of chromatograms using CodonCode Aligner (CodonCode Corporation). This included replicates within morphotypes, unknown species of Cortinarius sporocarps, and from selected sporocarps of known species: Elaphomyces muricatus (JF834198), Lactarius rufus (JF834199), Russula betularum (JF834200), and Russula fragilis (JF834201) collected in the study plots. Then all of those sequences with reference sequences were separated at a $97 \%$ similarity using assembly process under default criteria in CodonCode Aligner. Contigs obtained this way were aligned with ClustalW (CodonCode Aligner) and exported into neighbor joining using a number of differences model ("Appendix 2"). Selected sequences of studied ectomycorrhizal morphotypes (accession numbers HM015465-HM015482) and of selected sporocarps (accession numbers HQ115586-HQ115590; JF834198-JF834201) were published in GenBank.

\section{Statistics}

The relative abundance of each ectomycorrhizal morphotype was assessed by counting ectomycorrhizal root tips in each sample and expressing each ectomycorrhizal morphotype as a percentage of all fresh-looking ectomycorrhizal root tips collected from all samples of each tree 
species. After molecular verification, if it was found that different morphotypes were formed by the same EMF species, the EMF root tips of those morphotypes were summed and recalculated for the appropriate relative abundance. To assess the efficiency of ectomycorrhizal sampling, we constructed a species accumulation curve (Mao Tau), Chao 2, and first- and second-order Jackknife (Jackknife-1 and Jackknife-2, respectively) estimators of true species richness using the EstimateS program version 8.2.0 (Colwell 2009).

To examine the similarity of EMF communities among the tree species investigated, the Jaccard similarity indices were calculated: $P=(2 c / a+b) \times 100 \%$, where $a$ is the number of EMF species for tree $\mathrm{A}, b$ is the number of EMF species for tree $\mathrm{B}$, and $c$ is the number of EMF species shared between tree species A and tree species B. Jaccard indices were calculated including both belowground (ectomycorrhizas) and aboveground (sporocarps) EMF species.

Different EMF species (only for ectomycorrhizas) diversity indices (Shannon, Simpson, dominance, and evenness) among tree species studied were calculated using PAST 1.8 (Hammer et al. 2001). Comparison of belowground EMF species compositions was calculated using detrended correspondence analysis (DCA) by CANOCO software (Ter Braak and Šmilauer 2002).

\section{Results}

Ectomycorrhizal identification

In total, we described 31 ectomycorrhizal morphotypes on the four tree species studied ("Appendix 1"). Each morphotype found on each tree species was subjected to molecular analysis to identify the EMF species. The same ectomycorrhizal morphotypes collected from different host species were used as well to study any intra-morphotype variation among tree species ("Appendix 1"). After searching in GenBank and UNITE, the ITS sequences obtained from ectomycorrhizas and selected sporocarps were aligned with their best blastn matches.

All studied sequences and their best matches were separated at a $97 \%$ similarity using assembly process under other default criteria in CodonCode Aligner. We also incorporated sequences of selected sporocarps E. muricatus, L. rufus, $R$. betularum, and R. fragilis (JF834198-JF834201) collected in the study plots. The following sequences required assembling at either a $94 \%$ or $92 \%$ similarity threshold: HM015476 (morphotype 16 from Q. robur) and best match Humaria hemisphaerica (UDB000988) at 94\% and HM015475 (morphotype 15 from Q. rubra), HQ115589 and HQ115590 (sporocarps of Cortinarius sp. 1/51 and of Cortinarius sp. 1/52, respectively) and their best match Cortinarius vibratilis (UDB002397) at 92\%. Finally, we obtained 31 groups (contigs), each of which contained a specific reference, and thus were identified as different 31 species. EMF morphotypes and sporocarps that formed contigs at the similarity $<97 \%$ with their reference sequences were not identified to the species level ("Appendix 1").

An additional phylogenetic analysis for Cortinariaceae and Russulaceae was conducted using MEGA4.1 software (Trocha et al. 2006; Fig. 1). Using a molecular approach, among 31 ectomycorrhizal morphotypes described on four tree species ("Appendix 1"), we identified 31 EMF species (Table 2; Fig. 2). In some cases, different morphotypes were formed by the same EMF species, e.g., morphotype 8 and 53 (Paxillus involutus), whereas, in other cases, the same morphotype was formed by different EMF species depending on the host species (“Appendix 1").

\section{Efficiency of ectomycorrhizal sampling}

Species area curves (Mao-Tau) for the four tree species studied revealed an asymptotic pattern in total numbers of EMF species (data not shown). The total number estimator Chao-2 for $Q$. robur was 16.5, Jackknife-1 was 19.99, and Jackknife-2 was 18.98. Hence, the observed number of EMF species belowground ranged from around $80 \%$ to $97 \%$ of the estimated total number. The total number estimator Chao-2 for Q. rubra was 11.00 , Jackknife-1 was 11.99 , and Jackknife-2 was 12.00 . The observed EMF species total number comprised between $83 \%$ and $91 \%$ of the estimated richness. For P. sylvestris, Chao-2 was 15.98, Jackknife-1 was 15.98, and Jackknife-2 was 18.94. Thus, the observed EMF species total number comprised from about $69 \%$ to $81 \%$ of the estimated richness. P. nigra richness estimators were Chao-2 10.99, Jackknife-1 11.99, and Jackknife-2 13.96. The observed EMF species richness varied between $72 \%$ and $91 \%$ of estimated richness. Thus, we assumed that the ectomycorrhizal sampling efforts were sufficient for further analyses and discussion.

\section{Sporocarps identification}

Undesignated sporocarps of Cortinarius spp. were subjected to molecular identification the same way as ectomycorrhizas. The ITS of specimens representing five collections were sequenced (HQ155586-HQ115590), compared to NCBI and UNITE databases, and using 
Fig. 1 Phylogenetic analysis of Cortinariaceae and Russulaceae constructed using MEGA4.1 applying Kimura's twoparameter model. GenBank accession numbers from ectomycorrhizas or sporocarps studied and their best blastn matches are shown and all bootstrap values are indicated

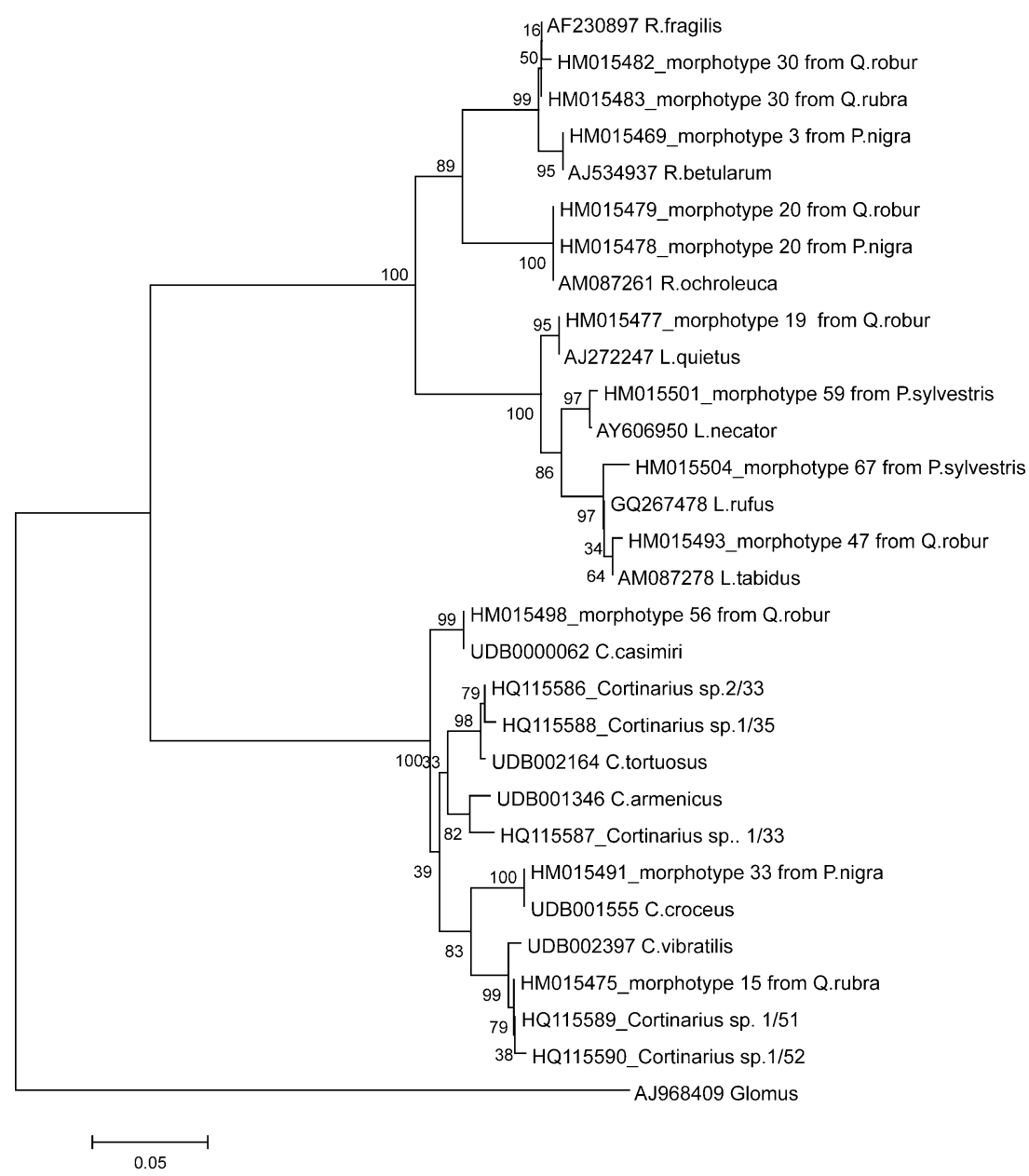

blastn search and phylogenetic analysis (Fig. 1), identified as four different species ("Appendix 1"). Molecular identification of the sporocarps of Cortinarius sp. 1/41 and Cortinarius sp. 1/49 (Fig. 2) was not possible as they were collected in a very poor condition. Remaining sporocarps were identified using standard procedures (see "Materials and methods"), and the data are presented in Fig. 2.

Comparison between sporocarp and ectomycorrhizal surveys

Combining DNA barcoding and morphotyping, 69 taxa of EMF species were recovered from root tips and found as sporocarps on the tree plots of the four host species studied (Fig. 2). Out of $69 \mathrm{EMF}$ species, $38 \mathrm{EMF}$ species were found only as sporocarps and 18 EMF only as ectomycorrhizas, whereas 13 were found both belowground and aboveground (Fig. 2). Basidiomycota were the most abundant EMF taxa both belowground and aboveground (Fig. 2). Among EMF species, we identified 25 species of Basidiomycota, five of Ascomycota, and one unidentified EMF (Fig. 2) on the four tree species. Aboveground, we found 49 species of Basidiomycota and two of Ascomycota. The most common fungal families, both belowground and aboveground, were Cortinariaceae (13 species) and Russulaceae (12 species; "Appendix 1"). The number of unique EMF species belowground was eight for $Q$. robur and three for $Q$. rubra, whereas for sporocarps the numbers were 19 and one, respectively (Fig. 2). P. sylvestris had six EMF species belowground and two aboveground, whereas P. nigra had four EMF species found as ectomycorrhizas and five found as sporocarps (Fig. 2).

The most frequently occurring EMF species (hereafter called multi-host) that occurred belowground on four tree species studied were $C$. geophilum Fr., P. involutus (Batsch) Fr., and Thelephoraceae sp. 1 (Table 2; Fig. 2). The EMF species with the highest frequency aboveground were Amanita gemmata (Fr.) Bertill. and P. involutus; both species were recorded under all tree species studied 
Table 2 Relative abundance ( \pm SE in parentheses) of belowground EMF species on native (Q. robur and P. sylvestris) and non-native tree species (Q. rubra and P. nigra) growing in a common garden experiment in Poland; $n=162$

\begin{tabular}{|c|c|c|c|c|}
\hline \multirow[t]{2}{*}{ Morphotype identity } & \multicolumn{4}{|c|}{ Relative abundance $(\%)$ of EMF species on host tree } \\
\hline & Quercus robur & Quercus rubra & Pinus sylvestris & Pinus nigra \\
\hline Cenococcum geophilum & $61.97( \pm 4.5)$ & $97( \pm 0.6)$ & $36.3( \pm 5.3)$ & $44.5( \pm 9.7)$ \\
\hline Paxillus involutus & $1( \pm 0.9)$ & $1( \pm 0.03)$ & $19.5( \pm 1.6)$ & $9.3( \pm 4.4)$ \\
\hline Thelephoraceae sp. 1 & $0.21( \pm 0.09)$ & $0.6( \pm 0.1)$ & $13.2( \pm 1.1)$ & $19.7( \pm 3.1)$ \\
\hline Russula ochroleuca & $0.37( \pm 0.37)$ & & & $9.3( \pm 6.4)$ \\
\hline Scleroderma citrinum & $0.25( \pm 0.15)$ & $0.07( \pm 0.06)$ & & \\
\hline Lactarius rufus & & & $0.7( \pm 0.6)$ & \\
\hline Tomentellopsis submollis & $0.17( \pm 0.08)$ & $0.2( \pm 0.05)$ & & \\
\hline Lactarius tabidus & $0.07( \pm 0.06)$ & & & \\
\hline Tylospora asterophora & & & $5.2( \pm 3.1)$ & $1.9( \pm 1.9)$ \\
\hline Boletus edulis & $0.9( \pm 0.8)$ & $0.03( \pm 0.03)$ & & \\
\hline Lactarius quietus & $33( \pm 4.1)$ & & & \\
\hline Russula fragilis & $0.37( \pm 0.33)$ & $0.37( \pm 0.3)$ & & \\
\hline Tomentella sublilacina & & & $1.1( \pm 1.1)$ & \\
\hline Tuber puberulum & & $0.4( \pm 0.35)$ & & \\
\hline Xerocomus badius & & & $7.3( \pm 3.8)$ & $4.8( \pm 2.7)$ \\
\hline Atheliaceae sp. 1 & & & $3.5( \pm 1.7)$ & $3.8( \pm 2)$ \\
\hline Elaphomyces muricatus & $0.04( \pm 0.03)$ & & & \\
\hline Lactarius necator & & & $0.3( \pm 0.3)$ & \\
\hline Thelephora terrestris & & & $2.1( \pm 0.9)$ & $3.4( \pm 0.8)$ \\
\hline Tomentella botryoides & & $0.03( \pm 0.03)$ & & \\
\hline Tomentellopsis sp. 1 & & & $9.6( \pm 1.8)$ & \\
\hline Clavulina sp. 1 & $0.36( \pm 0.17)$ & & & \\
\hline Cortinarius cf. vibratilis & & $0.13( \pm 0.03)$ & & \\
\hline Cortinarius casimiri & $0.21( \pm 0.14)$ & & & \\
\hline Cortinarius croceus & & & & $1.8( \pm 1.7)$ \\
\hline Humaria cf. hemispaerica & $1.1( \pm 0.9)$ & & & \\
\hline Pezizales sp. 1 & $0.15( \pm 0.14)$ & & & \\
\hline Russula betularum & & & & $1.6( \pm 1.5)$ \\
\hline Scleroderma sp. 1 & $0.21( \pm 0.1)$ & & & \\
\hline Pseudotomentella griseopergamacea & & & $1.1( \pm 1.1)$ & \\
\hline Unidentified EMF & & & $0.17( \pm 0.1)$ & \\
\hline
\end{tabular}

(Fig. 2). The remaining EMF species were less frequent or rare, either as ectomycorrhizas or sporocarps. The most abundant EMF species was C. geophilum for all tree species studied (36.3-97\%), followed by Lactarius quietus on $Q$. robur, (33\%), Thelephoraceae sp. 1 on $P$. nigra (19.7\%) and P. involutus on P. sylvestris (19.5\%; Table 2). Less abundant were Tomentellopsis sp. 1 on P. sylvestris (9.6\%), and P. involutus and Russula ochroleuca on $P$. nigra (9.3\% for each; Table 2). The other EMF species had low or very low $(<1 \%)$ relative abundance (Table 2$)$.

$Q$. robur was displayed the highest EMF species richness, both belowground and aboveground (Table 3) among the four tree species. P. nigra and Q. rubra hosted the lowest number of EMF species on their roots (Table 3). The lowest richness of EMF species as sporocarps was found under $P$. sylvestris (Table 3). $Q$. robur had ca. $100 \%$ higher total richness than non-native Q. rubra (Fig. 2; Table 3). P. sylvestris had ca. 30\% more of the belowground and ca. 50\% less of the aboveground EMF species richness as that of non-native $P$. nigra (Table 3).

EMF species community similarity and host preferences

Based on belowground EMF species occurrence and their relative abundances, we also calculated EMF 
Paxillus involutus

Xerocomus badius Boletus edulis

Russula fragilis

Lactarius rufus

Lactarius tabidus

Russula betularum

Russula ochroleuca

Cortinarius cf. vibratilis

Lactarius necator

Thelephora terrestris

Elaphomyces muricatus

Lactarius quietus

Cenococcum geophilum

Thelephoraceae sp. 1

Scleroderma citrinum

Tomentellopsis submollis

Tylospora asterophora

Atheliaceae sp. 1

Clavulina sp. 1

Cortinarius casimiri

Cortinarius croceus

Humaria cf. hemisphaerica

Pezizales sp. 1

Pseudotomentella griseopergamacea

Scleroderma sp. 1

Tomentella botryoides

Tomentella sublilacina

Tomentellopsis sp. 1

Tuber puberulum

unidentified EMF

Amanita gemmata

Amanita muscaria

Laccaria laccata

Lycoperdon nigrescen

Rhodocollybia butyracea f. asema

Amanita citrina

Amanita rubescens

Cantharellus cibarius

Cortinarius gentilis

Cortinarius sp. 1/41

Cortinarius tortuosus

Inocybe lacera

Rhodocollybia butyracea f. butyracea

Russula aeruginea

Xerocomus chrysenteron

Amanita pantherina

Cortinarius alboviolaceus

Cortinarius cf. cinnamomeus

Cortinarius flexipes

Cortinarius hemitrichus

Cortinarius torvus

Cortinarius armenicus

Cortinarius sp. 1/49

Gomphidius roseus

Hebeloma crustuliniforme

Humaria hemisphaerica

Hygrophorus hypothejus

Inocybe lanuginosa

Laccaria amethystina

Lactarius torminosus

Leccinum versipelle

Rhizopogon vinicolor

Russula amoenolens

Russula emetica

Russula xerampelina

Scleroderma verrucosum

Suillus bovinus

Suillus grevillei

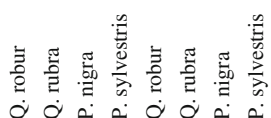

$\dot{\alpha} \dot{\alpha} \dot{\alpha} \dot{\alpha} \dot{\alpha}$

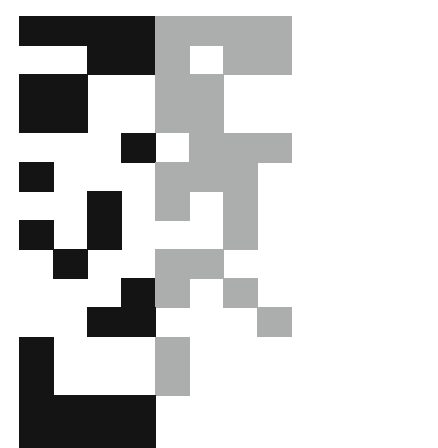

pecies dominance, Shannon and Simpson diversity indices, and evenness (Table 3). P. sylvestris and $P$. nigra displayed the highest EMF species diversity (both Shannon and Simpson), whereas Q. rubra displayed the lowest diversity (Table 3 ). The dominance index was the highest for $Q$. rubra and the lowest for $P$. sylvestris (Table 3). The evenness index was the highest for $P$. nigra followed by $P$. sylvestris, $Q$. robur, and the lowest on $Q$. rubra (Table 3).

Jaccard similarity indices showed that Pinus species shared the highest number of EMF species among all four species (61\%), followed by the two Quercus species (46\%). The lowest number of EMF species was shared between $P$. sylvestris and $Q$. robur (21\%). Additionally, detrended correspondence analysis showed a higher resemblance between $P$. sylvestris and $P$. nigra EMF communities than between $Q$. robur and $Q$. rubra EMF communities (data not shown). The least divergent EMF species was C. geophilum for all tree species. The most common EMF species for both oaks were Tomentellopsis submollis and $R$. fragilis, whereas for the pines they were Thelephora terrestris and Xerocomus badius. Several EMF species exclusively associated with particular tree species: Lactarius tabidus, L. quietus, E. muricatus, Clavulina sp. 1, Cortinarius casimiri, H. cf. hemisphaerica, Pezizales sp. 1, and Scleroderma sp. 1 to Q. robur; Tuber puberulum, Tomentella botryoides, and $C$. cf. vibratilis to $Q$. rubra; Cortinarius croceus and $R$. betularum to $P$. nigra; and L. rufus, Tomentella sublilacina, Lactarius necator, Tomentellopsis sp. 1, and Pseudotomentella griseopergamacea to $P$. sylvestris.

\section{Discussion}

Plant host identity is a key factor influencing ectomycorrhizal fungal community structure with greater phylogenetic distance of the hosts leading to greater dissimilarity of fungal communities between host species (Ishida et al. 2007; Tedersoo et al. 2008). Additionally, native host species that have had a relatively extended period of coevolution with the fungal mycorrhizal community may have more diverse fungal communities than those of introduced host species. To test this assumption, we 
Table 3 EMF species richness (above-, belowground, and total) and EMF species diversity (only for belowground) indices including Shannon and Simpson, evenness and dominance for four tree species studied

\begin{tabular}{|c|c|c|c|c|c|c|c|}
\hline \multirow[t]{2}{*}{ Host tree } & \multicolumn{3}{|l|}{ Richness (S) } & \multicolumn{4}{|l|}{ Diversity } \\
\hline & Belowground & Aboveground & Total & Dominance $(D)$ & Shannon $(H)$ & Simpson $(1-D)$ & Evenness $\left(e^{\wedge} H / S\right)$ \\
\hline P. sylvestris & 13 & 12 & 21 & 0.22 & 1.92 & 0.78 & 0.52 \\
\hline P. nigra & 10 & 22 & 28 & 0.29 & 1.77 & 0.71 & 0.58 \\
\hline Q. robur & 16 & 37 & 49 & 0.53 & 0.94 & 0.47 & 0.16 \\
\hline Q. rubra & 10 & 14 & 21 & 0.98 & 0.17 & 0.02 & 0.12 \\
\hline
\end{tabular}

compared EMF species communities between a native and exotic oak ( $Q$. robur and $Q$. rubra) and a native and exotic pine ( $P$. sylvestris and P. nigra) growing in a common garden experimental forest stand in Poland.

We found that native and non-native tree species within the genera Pinus and Quercus shared many EMF species and exhibited no systematic difference in diversity across genera. In Quercus, there was clearly higher richness and diversity in the native $Q$. robur than in the exotic, Q. rubra, while in Pinus, the total richness was higher for non-native P. nigra whereas the belowground richness and diversity was lower for that tree species (Table 3). In contrast to our study, Gebhardt et al. (2007) found a higher total number of distinctive EMF species ( 32 vs. 22 in this study) in a 46-year-old Q. rubra stand in Germany, indicating that the number of EMF species in Q. rubra is not uniformly low outside its natural range. Non-native tree species were able to form ectomycorrhizal assemblages with fungi that naturally occurred on the study site. Similar EMF species communities within the genera Quercus and Pinus probably results from sharing the same habitat conditions, stand history and successional status, as well as the same type of adjacent forest (Cline et al. 2005; Ishida et al. 2007). The similarity also results from a high proportion of EMF species with a broad host range (found in both angiosperms and gymnosperms). All this, in turn, may explain successful adaptation of the trees to local conditions and their competitive growth and survival (Reich et al. 2005).

Ectomycorrhizal fungal species like $C$. geophilum and $P$. involutus were present on all hosts, while fungi with stronger host preferences (unique EMF species) were present on one or two tree species (Table 2; Fig. 2). A similar pattern was found by Newton (1991) who found that $B$. pendula and $Q$. robur shared only three EMF species $(C$. geophilum, $P$. involutus, and Scleroderma citrinum) out of 41 described in that study. Horton and Bruns (1998) also observed that Douglas fir (P. menziesii) and bishop pine
(Pinus muricata) growing in a mixed stand shared some EMF species, while some of them were also unique to each tree species. The fact that different tree species growing in the same habitat conditions share EMF species may indicate that these fungi exhibit a broad ecological profile and do not display narrow host preferences. However, studies on EMF species communities of co-occurring species of Quercus and Pinus sabiniana showed that the multi-host species might be much less dominant (Smith et al. 2009).

The dominance of C. geophilum on the four tree species in this study may be affected by the high competitive abilities and wide ecological amplitude of this fungus (Pigott 1982; Jonsson et al. 1999; Izzo et al. 2005). Moreover, that $C$. geophilum reaches its highest relative abundance on Q. rubra (Table 2) rather than the other tree species studied may be of interest. The dominance index was the highest for $Q$. rubra, while the evenness index was the lowest for that tree species indicating that the belowground EMF community was strongly affected by C. geophilum (Table 3). Walker et al. $(2005,2008)$ showed that $C$. geophilum was the most frequent and abundant EMF species on $Q$. rubra seedlings growing in North America. However, the abundance of $C$. geophilum was much lower $(<37 \%)$ in the studies of Walker et al. (2008) than on $Q$. rubra in our study. Hence, the dominance of $C$. geophilum on $Q$. rubra in a novel habitat (see also Gebhardt et al. 2007) may be of ecological interest. Moreover, it has been also discovered that $C$. geophilum is a complex species (see Douhan et al. 2007). Thus, quantifying root tips typical of this EMF species based on its unique morphology may underestimate the actual number of EMF species.

At least half of the EMF species recorded in this study are known to occur naturally both in Europe and North America. Most of them were recorded in association with oaks in the present study (e.g., C. geophilum, Boletus edulis, P. involutus, $R$. fragilis, S. citrinum; “Appendix 1"). Some of the taxa found in this study also formed 
ectomycorrhizas with $Q$. rubra within its natural distribution range, e.g., A. gemmata, C. geophilum, Laccaria laccata (Walker et al. 2005). Holarctic distribution of these symbionts may enhance successful introduction of $Q$. rubra on the European continent. However, the finding that $T$. puberulum, a species of European distribution (Jeandroz et al. 2008), forms ectomycorrhizas with $Q$. rubra shows that the tree is able to accept new symbionts as well.

It is well documented that the lack of EMF species hinders both introductions and invasions of Pinaceae in the southern hemisphere (see Nuñez et al.). In our study, we found similar EMF community composition of non-native $P$. nigra and native $P$. sylvestris (see "Results") as well as a considerable number of EMF species found uniquely in association with $P$. nigra. This could result from the mainly European distribution of both tree species, partial overlap of their ranges, and panEuropean distribution of many of their ectomycorrhizal symbionts. In the mountainous region in Spain, where both pines co-occur naturally, sporocarps of at least 115 EMF species were found in stands of $P$. nigra (Martínez de Aragón et al. 2007), and two thirds of them were also common for P. sylvestris. Eight of these species were also present in our experimental plots, although none of them was found in association with P. nigra. Most of them are known to occur in East Europe; thus, potentially P. nigra occurrence here should not be limited by the lack of ectomycorrhizal fungal inoculum. However, as shown by Bonfante et al. (1998), strains originating from a specific site show better symbiotic capabilities in association with host plants growing in the same type of environment. The robust occurrence of native EMF symbionts on $Q$. rubra and $P$. nigra growing in our experiment may be due to the fact that initial introduction was conducted via acorns and seeds, since most contemporary stands were established using acorns and seeds from old domestic plantations. Tedersoo et al. (2007) found that introduced P. caribea in the Seychelles maintained EMF species co-introduced with seedlings. Considerable similarity in EMF species community structure between $Q$. robur and $Q$. rubra and between $P$. sylvestris and $P$. nigra (Jaccard similarity index and DCA-see "Results") confirms the observations that tree species of the same genus or family tend to form similar EMF assemblages (Newton and Haigh 1998; Ishida et al. 2007). The similarity of EMF species communities within the same tree genus may be an effect of host plant preferences toward to genus-specific or even species-specific ectomycorrhizal fungi (Allen 1991; Tedersoo et al. 2008; Smith et al. 2009). Kennedy et al. (2003) showed that dominant canopy (Pseudotsuga menziesii) and understorey (Lithocarpus densiflora) shared around $30 \%$ of EMF species suggesting a high potential for common mycorrhizal networks to form between trees. Ishida et al. (2007) found the most similar EMF structures for closely related tree species or due to their successional status. However, the EMF species communities of closely related tree species may differ from each other significantly as well, as shown by Morris et al. (2008) for Quercus spp. and Korkama et al. (2006) for clones of Picea abies.

Data presented in this study indicate that lack of sufficient geographic barriers for numerous EMF fungi, which exhibit broad distribution and low host specificity, a long history of introduction and afforestation of studied tree species, as well as trade of potted seedlings, allow for effective growth of exotic tree species outside their natural ranges. Cullings et al. (2000) found no specific EMF species colonizing roots of invasive Picea engelmannii trees growing together with native Pinus contorta in the Yellowstone National Park. Parladé et al. (1996) found that many EMF species native to Spain formed ectomycorrhizas with introduced Pseudotsuga menziesii. Tedersoo et al. (2007) also observed that native EMF species colonized introduced eucalypts in the Seychelles. However, Dickie et al. (2010a) found that invasive $P$. contorta had no mutualistic associations with native EMF in New Zealand. On the other hand, exotic EMF species present on roots of introduced trees may also invade novel territories if they find new hosts (Díez 2005).

In summary, the results presented in this study show that tree species, both non-native and native belonging to the same genus, share EMF species and form similar EMF species communities. This supports naturalization of nonnative trees by means of mutualistic associations with cosmopolitan and novel fungi. We found no systematic difference in fungal richness of native hosts compared to non-native hosts across genera. Native Pinus sylvestris and non-native Pinus nigra have more similar EMF communities than native Quercus robur and non-native Quercus rubra. Our research also demonstrates that dominant EMF species is the same for different host genera or for different host species within the same genus.

Acknowledgments This research was made possible by Polish Science Committee grant PBZ-KBN-087/P04/2003 and grant of Polish Ministry of Science and Higher Education (N304 01232/ 0934). The authors would like to thank Barbara Werner for her help in field and laboratory. The authors are grateful Dr. Marek Kasprowicz and Dr. Kabir Peay for their assistance in statistics. We are cordially thankful to Dr. David M. Eissenstat, Dr. Lee E. Frelich, M. Luke McCormack, Dr. Randy Molina, and two anonymous reviewers for their thoughtful comments and suggestions.

Open Access This article is distributed under the terms of the Creative Commons Attribution Noncommercial License which permits any noncommercial use, distribution, and reproduction in any medium, provided the original author(s) and source are credited. 


\section{Appendix 1}

Table 4 Identification of ectomycorrhizal morphotypes associated with Q. robur, Q. rubra, P. sylvestris, and P. nigra

Ectomycorrhizas Morphotype no.

53

11

12

13

15

16

19

20

20

28

29

30

30

31

31

$31 \mathrm{a}$

32

32

32

32

33

45

47

54

55

56

57

58

59

60

60

67

24

Sporocarps

Specimen name

Cortinarius 2/33

Cortinarius $1 / 33$

Cortinarius $1 / 35$

Cortinarius $1 / 51$

Cortinarius $1 / 52$
HM015466

HM015467

HM015468

HM015469

HM015470

HM015471

HM015494

HM015495

HM015472

HM015473

HM015474

HM015475

HM015476

HM015477

HM015478

HM015479

HM015480

HM015481

HM015482

HM015483

HM015484

HM015485

HM015486

HM015487

HM015488

HM015489

HM015490

HM015491

HM015492

HM015493

HM015496

HM015497

HM015498

HM015499

HM015500

HM015501

HM015502

HM015503

HM015504

HM015505

Specimen acc. no.

HQ115586

HQ115587

HQ115588

HQ115589

HQ115590
Host tree

P. nigra

P. sylvestris

Q. robur

Q. rubra

P. nigra

P. nigra

Q. robur

P. sylvestris

Q. rubra

P. nigra

P. sylvestris

Q. robur

Q. rubra

Q. robur

Q. robur

P. nigra

Q. robur

Q. rubra

Q. robur

Q. robur

Q. rubra

P. nigra

P. sylvestris

P. sylvestris

Q. robur

Q. rubra

P. nigra

P. sylvestris

P. nigra

Q. rubra

Q. rubra

Q. robur

Q. robur

Q. robur

Q. robur

Q. robur

P. sylvestris

P. nigra

P. sylvestris

P. sylvestris

P. sylvestris

Host tree

P. nigra

P. nigra

Q. robur

Q. rubra

Q. robur
Best match acc. no. (NCBI and/or UNITE)

Uncultured Thelephoraceae (AF430259)

Uncultured Thelephoraceae (AF430259)

Uncultured Thelephoraceae (AF430259)

Uncultured Thelephoraceae (AF430259)

Russula betularum (AJ534937)

Paxillus involutus (DQ179126)

Paxillus involutus (EU819416)

Paxillus involutus (EU819416)

Paxillus involutus (FR750011)

Tylospora asterophora (AF052557)

Pseudotomentella griseopergamacea (UDB001617)

Scleroderma areolatum (FM213352) and $S$. verrucosum (UDB000044)

Cortinarius vibratilis (UDB002397)

Humaria hemisphaerica (UDB000988)

Lactarius quietus (AJ272247)

Russula ochroleuca (AM087261)

Russula ochroleuca (AM087261)

Tuber puberulum (AJ969626)

Tomentellopsis submollis (AJ410773)

Russula fragilis (AF230897)

Russula fragilis (AF230897)

Uncultured Atheliaceae (EU557324)

Uncultured Atheliaceae (EU557324)

Tomentella sublilacina (UDB000970)

Boletus edulis (DQ131622)

Boletus edulis (HM57930)

Xerocomus badius (AJ889926)

Xerocomus badius (AJ889926)

Dermocybe crocea (U56038)

and Cortinarius croceus (UDB001555)

Tomentella botryoides (UDB000256)

Lactarius tabidus (AM087278)

Scleroderma citrinum (GQ166907)

Clavulina sp. (AJ534709)

Cortinarius casimiri (UDB000062)

Elaphomyces muricatus JF834198

Uncultured Pezizales (AJ969619)

Lactarius necator (AY606950)

Thelephora terrestris (UDB000971)

Thelephora terrestris (UDB000971)

Lactarius rufus (GQ267478)

Tomentellopsis echinospora (UDB000183)

Best match acc. no. (NCBI and/or UNITE)

Cortinarius tortuosus (UDB002164)

Cortinarius armenicus (UDB001346)

Cortinarius tortuosus (UDB002164)

Cortinarius vibratilis (UDB002397)

Cortinarius vibratilis (UDB002397)
Identity $(\%)$

$564 / 573$ (98)

$602 / 636(95)$

$554 / 580(96)$

$540 / 565(96)$

$503 / 503(100)$

$540 / 565(96)$

$775 / 793$ (98)

$621 / 629(99)$

$591 / 606$ (98)

445/463 (96)

$593 / 594$ (99)

$661 / 671(99)$ and

609/613 (99)

$509 / 544$ (93)

373/401 (93)

650/664 (98)

$560 / 587$ (95)

606/609 (99)

481/482 (99)

$562 / 565$ (99)

548/564 (97)

$564 / 572$ (99)

409/432 (95)

576/578 (99)

$575 / 578$ (99)

$557 / 558$ (99)

548/596 (92)

$521 / 528$ (99)

$521 / 526$ (99)

$532 / 552$ (96) and

$520 / 524$ (99)

$568 / 568(100)$

$581 / 584$ (99)

503/513 (98)

$530 / 550(96)$

484/487 (99)

508/520 (98)

$530 / 538$ (99)

455/461 (99)

558/583 (96)

$575 / 590$ (97)

$509 / 618$ (95)

349/355 (98)

Identity (\%)

578/581 (98)

558/572(97)

$581 / 591$ (98)

530/561 (94)

$578 / 626(92)$

Morphotype identity

Thelephoraceae sp. 1

Thelephoraceae sp. 1

Thelephoraceae sp. 1

Thelephoraceae sp. 1

Russula betularum

Paxillus involutus

Paxillus involutus

Paxillus involutus

Paxillus involutus

Tylospora asterophora

Pseudotomentella griseopergamacea

Scleroderma sp. 1

Cortinarius cf. vibratilis

Humaria cf. hemisphaerica

Lactarius quietus

Russula ochroleuca

Russula ochroleuca

Tuber puberulum

Tomentellopsis submollis

Russula fragilis

Russula fragilis

Atheliaceae sp. 1

Atheliaceae sp. 1

Tomentella sublilacina

Boletus edulis

Boletus edulis

Xerocomus badius

Xerocomus badius

Cortinarius croceus

Tomentella botryoides

Lactarius tabidus

Scleroderma citrinum

Clavulina sp. 1

Cortinarius casimiri 


\section{Appendix 2}

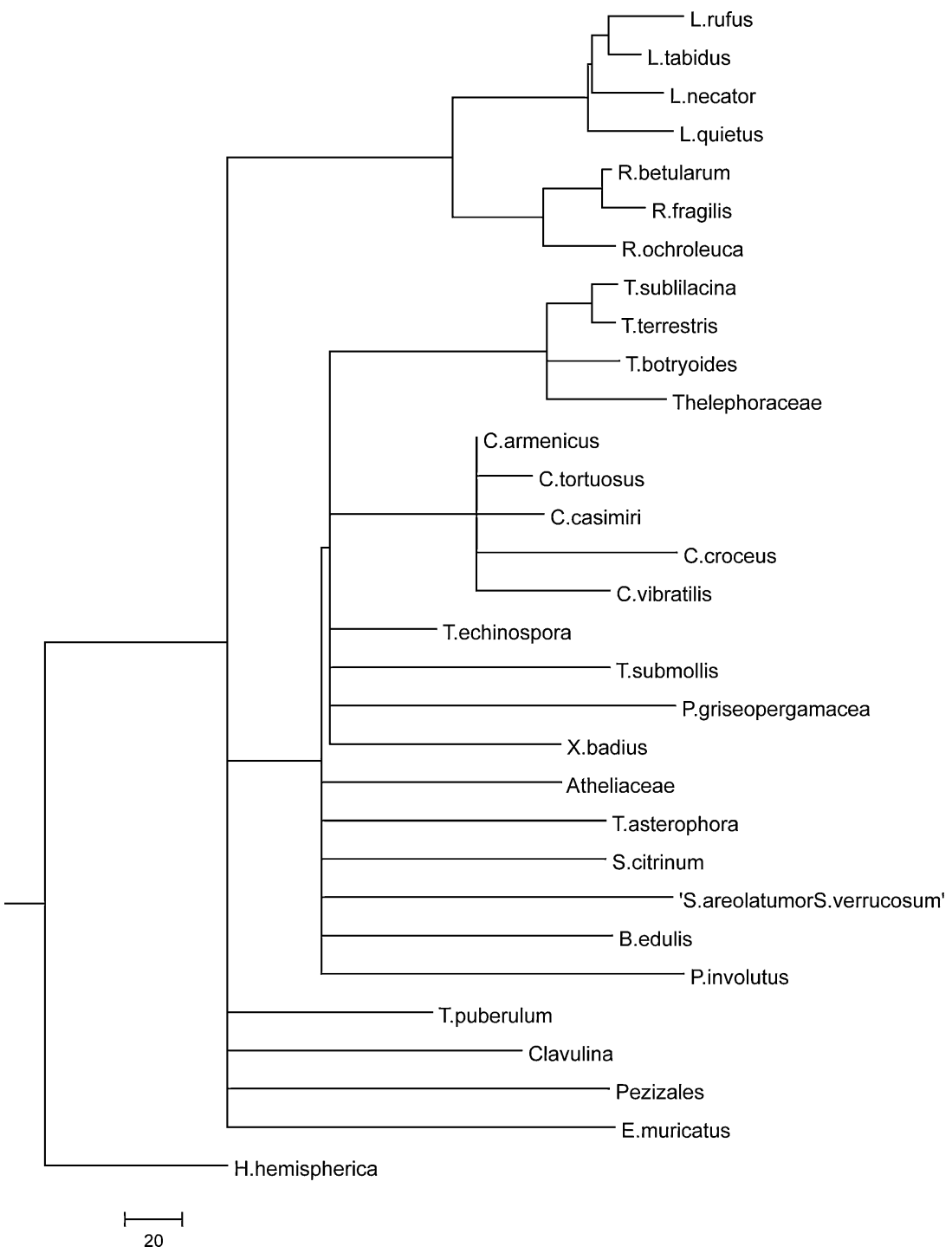

Fig. 3 Dendrogram of contigs derived from CodonCode Aligner using ITS sequences obtained from EMF morphotypes, selected sporocarps, and their best matches from GenBank, UNITE matches, and sporocarps collected in the study plots

\section{References}

Agerer R (1987-2003) Colour atlas of ectomycorrhizae. Einhorn, Schwäbisch Gmünd

Allen MF (1991) The ecology of mycorrhizae (Cambridge Studies in Ecology). Cambridge University Press, UK

Bellon S, Tumiłowicz J, Król S (1977) Obce gatunki drzew w gospodarstwie leśnym. PWRiL, Warszawa

Białobok S, Chylarecki H (1965) Badania nad uprawą drzew obcego pochodzenia w Polsce w warunkach środowiska leśnego. Arbor Kórnickie 10:211-277

Bonfante P, Balestrini R, Martino E, Perotto S, Plassard C, Mousain D (1998) Morphological analysis of early contacts between pine roots and two ectomycorrhizal Suillus strains. Mycorrhiza 8:1-10
Brisco CB (1959) Early results of mycorrhizal inoculations of pine in Puerto Rico. Carrib For 20:73

Cairney JWG (2000) Evolution of mycorrhiza systems. Naturwissenschaften $87: 467-475$

Chou-Chou M, Grace LJ (1983) Characterization and identification of mycorrhizas of Douglas-fir in New Zealand. Eur J For Pathol $13: 251-260$

Cline ET, Ammirati JF, Edmonds RL (2005) Does proximity to mature trees influence ectomycorrhizal fungus communities of Douglas-fir seedling? New Phytol 166:993-1009

Colwell RK (2009) Statistical estimation of species richness and shared species from samples. EstimateS Version 8.2 at: http:// viceroy.eeb.uconn.edu/EstimateS

Cullings KW, Vogler DR, Parker VT, Finley SK (2000) Ectomycorrhizal specificity patterns in a mixed Pinus contorta and Picea 
engelmannii forest in Yellowstone National Park. Appl Environ Microbiol 66:4988-4991

Daubree JB, Kremer A (1993) Genetic and phonological differentiation between natural and introduced populations of Quercus rubra L. Ann For Sci 50:271-280

Dauer JM, Chorover J, Chadwick OA, Oleksyn J, Tjoelker MG, Hobbie SE, Reich PB, Eissenstat DE (2007) Controls over leaf and litter calcium concentrations among temperate trees. Biogeochemistry $86: 175-187$

Dauer JM, Withington JM, Oleksyn J, Chorover J, Chadwick OA, Reich PB, Eissenstat DM (2009) A scanner-based approach to soil profilewall mapping of root distribution. Dendrobiology 62:35-40

Demchik MC, Sharpe WE (2000) The effect of soil nutrition, soil acidity and drought on northern red oak (Quercus rubra L.) growth and nutrition on Pennsylvania sites with high and low red oak mortality. For Ecol Manag 136:199-207

Dickie IA, Oleksyn J, Reich PB, Karolewski P, Zytkowiak R, Jagodzinski AM, Turzanska E (2006) Soil modification by different tree species influences the extent of seedling ectomycorrhizal infection. Mycorrhiza 16:73-79

Dickie IA, Bolstridge N, Cooper JA, Peltzer DA (2010a) Co-invasion by Pinus and its mycorrhizal fungi. New Phytol 187:475-484

Dickie IA, Kałucka I, Stasińska M, Oleksyn J (2010b) Plant host drives fungal phenology. Fungal Ecol 3:311-315

Díez J (2005) Invasion biology of Australian ectomycorrhizal fungi introduced with eucalypt plantations into the Iberian Peninsula. Biol Invasions 7:3-15

Douhan GW, Huryn KL, Douhan LI (2007) Significant diversity and potential problems associated with inferring population structure within the Cenococcum geophilum species complex. Mycologia 99:812-819

Gardes M, Bruns TD (1993) ITS primers with enhanced specificity for basidiomycetes - application to the identification of mycorrhizae and rusts. Mol Ecol 2:113-118

Gebhardt S, Neubert K, Wöllecke J, Münzenburger B, Hütl RF (2007) Ectomycorrhiza communities of red oak (Quercus rubra L.) of different age in the Lusatian lignite mining district, East Germany. Mycorrhiza 17:279-290

Goebel M, Hobbie SE, Bulaj B, Zadworny M, Archibald DD, Oleksyn J, Reich PB, Eissenstat DM (2011) Decomposition of the finest root branching orders: linking carbon and nutrient dynamics belowground to fine root function and structure. Ecol Monogr 81:89-102

Grubisha LC, Bergemann SE, Bruns TD (2007) Host islands within the California Northern Channel Islands create fine-scale genetic structure in two sympatric species of the symbiotic ectomycorrhizal fungus Rhizopogon. Mol Ecol 16:1811-1822

Hammer O, Harper DAT, Ryan PD (2001) PAST: palaeontological statistics software package for education and data analysis. Palaeontol Electronica 4:9

Hobbie SE, Reich PB, Oleksyn J, Ogdahl M, Zytkowiak R, Hale C, Karolewski P (2006) Tree species effects on decomposition and forest floor dynamics in a common garden. Ecology 87:2288-2297

Hobbie SE, Ogdahl M, Chorover J, Chadwick OA, Oleksyn J, Zytkowiak R, Reich PB (2007) Tree species effects on soil organic matter dynamics: the role of soil cation composition. Ecosystems 10:999-1018

Hobbie SE, Oleksyn J, Reich PB, Eissenstat DE (2010) Fine root decomposition rates do not mirror those of leaf litter among temperate tree species. Oecologia 162:505-513. doi:10.1007/ s00442-009-1479-6

Horton TR, Bruns TD (1998) Multiple-host fungi are the most frequent and abundant ectomycorrhizal types in a mixed stand of
Douglas fir (Pseudotsuga menziesii) and bishop pine (Pinus muricata). New Phytol 139:331-339

Ingleby K, Mason PA, Last FT, Fleming LV (1990) Identification of ectomycorrhizas. Institute of Terrestrial Ecology Research publication no. 5. HMSO, London

Ishida TA, Nara K, Hogetsu T (2007) Host effects on ectomycorrhizal fungal communities: insight from eight host species in mixed conifer-broadleaf forests. New Phytol 174:430-440

Iwański M, Rudawska M, Leski T (2006) Mycorrhizal associations of nursery grown Scots pine (Pinus sylvestris L.) seedlings in Poland. Ann For Sci 63:715-723

Izzo A, Agbowo J, Bruns TD (2005) Detection of plot-level changes in ectomycorrhizal communities across years in an old-growth mixed-conifer forest. New Phytol 166:619-630

Jeandroz S, Murat C, Wang Y, Bonfante P, Le Tacon F (2008) Molecular phylogeny and historical biogeography of the genus Tuber, the 'true truffles'. J Biogeogr 35:815-829

Jonsson L, Dahlberg A, Nilsson MC, Kåren O, Zackrisson O (1999) Continuity of ectomycorrhizal fungi in self-regenerated boreal Pinus sylvestris forests studied by comparing mycobiont diversity on seedlings and mature trees. New Phytol 142:151-162

Kennedy PG, Izzo AD, Bruns TD (2003) There is high potential for the formation of common mycorrhizal networks between understorey and canopy trees in a mixed evergreen forest. J Ecol 91:1071-1080

Knight KS, Oleksyn J, Jagodzinski AM, Reich PB, Kasprowicz M (2008) Overstory tree species regulate colonization by native and exotic plants: a source of positive relationships between understorey diversity and invasibility. Divers Distrib 14:666-675

Knudsen HJ, Vesterholt J (2008) Funga Nordica. Agaricoid, boletoid and cyphelloid genera. Nordsvamp, Copenhagen

Kohout $\mathrm{P}$, Sýkorová Z, Bahram M, Hadincová V, Albrechtová J, Tedersoo L, Vohník M (2010) Ericaceous dwarf shrubs affect ectomycorrhizal fungal community of the invasive Pinus strobus and native Pinus sylvestris in a pot experiment. Mycorrhiza. doi:10.1007/s00572-010-0350-2

Korkama T, Pakkanen A, Pennanen T (2006) Ectomycorrhizal community structure varies among Norway spruce (Picea abies) clones. New Phytol 171:815-824

Kretzer A, Li YN, Szaro T, Bruns TD (1996) Internal transcribed spacer sequences from 38 recognized species of Suillus sensu lato: phylogenetic and taxonomic implications. Mycologia 88:776-785

Křivánek M, Pyšek P (2006) Predicting invasions by woody species in a temperate zone: a test of three risk assessment schemes in the Czech Republic (Central Europe). Divers Distrib 12:319-327

Legon NW, Henrici A, Roberts PJ, Spooner BM, Watling R (eds) (2005) Checklist of the British and Irish Basidiomycota. Royal Botanic Gardens, Richmond

Martínez de Aragón J, Bonet JA, Fischer CR, Colinas C (2007) Productivity of ectomycorrhizal and selected edible saprotrophic fungi in pine forests of the pre-Pyrenees mountains, Spain: predictive equations for forest management of mycological resources. For Ecol Manag 252:239-256

Morris MH, Smith ME, Rizzo DM, Rejmánek M, Bledsoe CS (2008) Contrasting ectomycorrhizal fungal communities on the roots of co-occurring oaks (Quercus spp.) in a California woodland. New Phytol 178:167-176

Newton AC (1991) Mineral nutrition and mycorrhizal infection of seedling oak and birch III. Epidemiology aspects of ectomycorrhizal infection, and the relationship with seedling growth. New Phytol 117:53-60

Newton AC, Haigh JM (1998) Diversity of ectomycorrhizal fungi in Britain: a test of the species-area relationship, and the role of host specificity. New Phytol 138:619-627 
Nuñez MA, Horton TR, Simberloff D (2009) Lack of belowground mutualisms hinders Pinaceae invasions. Ecology 90:2352-2359

Parladé J, Álvarez IF, Pera J (1996) Ability of native ectomycorrhizal fungi from northern Spain to colonize Douglas-fir and other introduced conifers. Mycorrhiza 6:51-55

Petit RJ, Bialozyta R, Garnier-Géré P, Hampe A (2004) Ecology and genetics of tree invasions: from recent introductions to Quaternary migrations. For Ecol Manag 197:117-137

Pigott CD (1982) Survival of mycorrhiza formed by Cenococcum geophilum Fr. in dry soils. New Phytol 92:513-517

Poynton RJ (1979) The pines. Tree planting in southern Africa. Department of Forestry, Pretoria, In, pp 1-576

Reich PB, Oleksyn J, Modrzyński J, Mroziński P, Hobbie SA, Eissenstat DM, Chorover J, Chadwick OA, Hale CM, Tjoelker MG (2005) Linking litter calcium, earthworms and soil properties: a common garden test with 14 tree species. Ecol Lett 8:811-818

Reinhart KO, Callaway RM (2006) Soil biota and invasive plants. New Phytol 170:445-457

Richardson DM, Williams PA, Hobbs RJ (1994) Pine invasions in the Southern Hemisphere: determinants of spread and invadability. J Biogeo 21:511-527

Rudawska M, Leski T, Trocha LK, Gornowicz R (2006) Ectomycorrhizal status spruce seedlings from bare-root forest nurseries. For Ecol Manag 236:375-384

Rusca TA, Kennedy PG, Bruns TD (2006) The effect of different pine hosts on the sampling of Rhizopogon spore banks in five Eastern Sierra Nevada forests. New Phytol 170:551-560

Smith SE, Read DJ (2008) Mycorrhizal symbiosis, 3rd edn. Academic Press (Elsevier), Oxford

Smith ME, Douhan GW, Fremier AK, Rizzo DM (2009) Are true multihost fungi the exception or the rule? Dominant ectomycorrhizal fungi on Pinus sabiniana differ from those on co-occurring Quercus species. New Phytol 182:295-299

Tedersoo L, Suvi T, Beaver K, Kõljalg U (2007) Ectomycorrhizal fungi of the Seychelles: diversity patterns and host shifts from the native Vateriopsis seychellarum (Dipterocarpaceae) and Intsia bijuga (Caesalpiniaceae) to the introduced Eucalyptus robusta (Myrtaceae), but not Pinus caribea (Pinaceae). New Phytol 175:321-333
Tedersoo L, Jairus T, Horton BM, Abarenkov K, Suvi T, Saar I, Kõljalg U (2008) Strong host preference of ectomycorrhizal fungi in a Tasmanian wet sclerophyll forest as revealed by DNA barcoding and taxon-specific primers. New Phytol 180:479-490

Ter Braak CJF, Šmilauer P (2002) CANOCO reference manual and user's guide to Canoco for Windows 4.5: software for canonical community ordination. MicroComputer Power, Ithaca

Trocha LK, Rudawska M, Leski T, Dabert M (2006) Genetic diversity of naturally established ectomycorrhizal fungi on Norway spruce seedlings under nursery conditions. Microb Ecol 52:418-425

Vellinga EC, Wolfe BE, Pringle A (2009) Global patterns of ectomycorrhizal introductions. New Phytol 181:960-973

Walker JF, Miller OK Jr, Horton JL (2005) Hyperdiversity of ectomycorrhizal fungus assemblages on oak seedlings in mixed forests in the southern Appalachian Mountains. Mol Ecol 14:829-838

Walker JF, Miller OK Jr, Horton JL (2008) Seasonal dynamics of ectomycorrhizal fungus assemblages on oak seedlings in the southeastern Appalachian Mountains. Mycorrhiza 18:123-132

White TJ, Bruns T, Lee S, Taylor J (1990) Amplification and direct sequencing of fungal ribosomal RNA genes for phylogenetics. In: Innis DHGMA, Sninsky JJ, White TJ (eds) PCR protocols: a guide to methods and applications. Academic, New York, pp 315-322

Withington JM, Elkin AD, Bulaj B, Olesinski J, Tracy KN, Bouma TJ, Oleksyn J, Anderson LJ, Modrzynski J, Reich PB, Eissenstat DM (2003) The impact of material used for minirhizotron tubes for root research. New Phytol 160:533-544

Withington JM, Reich PB, Oleksyn J, Eissenstat DM (2006) Comparison of structure and life span in roots and leaves among temperate trees. Ecol Monogr 76:381-397

Zerbe S, Wirth P (2006) Non-indigenous plant species and their ecological range in Central European pine (Pinus sylvestris L.) forests. Ann For Sci 63:189-203

Zhou M, Sharik TL, Jurgensen MF, Richter DL (1997) Ectomycorrhizal colonization of Quercus rubra seedlings in response to vegetation removals in oak and pine stands. For Ecol Manag 93:91-99 